\title{
ANALISIS PENERAPAN SISTEM INFORMASI MANAJEMEN DAERAH (SIMDA) KEUANGAN DALAM PENGELOLAAN KEUANGAN DAERAH PEMERINTAH KOTA MANADO
}

\author{
Juddy Julian Pilat, Jullie J. Sondakh, Hendrik Manossoh \\ (Email: jjulian189@gmail.com)
}

\begin{abstract}
Local autonomy gives authority to local governments to implement their own financial management, which led to public accountability through the presentation of financial statements to the public. The obligation of governments to use information technology to simplify and improve the ability of financial data processing. Implementation of an integrated Financial LMIS can facilitate financial management to produce financial information that is integrated, comprehensive, precise and accurate. The purpose of this research is to (1). analyze the supporting factors owned by Manado City Government in order to implement the Financial LMIS, (2). analyze Financial LMIS as a local financial information system in assisting the local financial management and (3). analyze internal control of Financial LMIS in financial data processing. The analytical method used is qualitative descriptive phenomenology. Qualitative data were obtained by indepth interviews, observation and documentation. Validity and reliability of the data were determined by data and resources triangulation. The acquired data were coded into patterns and analysed, data interpretation and conclusion. Results of research and analysis indicate that Manado City Government had supporting factors such in order to implement the Financial LMIS optimally such as: communication, resources, disposition/attitude and bureaucratic structures. Financial LMIS is very important and very helpful in helping an integrated local financial management as well as play a role in order to: support the organization's operations, support decision making and support the achievement of strategic goals and objectives of the organization. Financial LMIS has been supported by adequate internal controls to ensure the effectiveness and efficiency implementation of a system that has been designed with some type of control, such as: control of access and user authority, control of physical security, control of menu based functions and control of applications.

Keywords: Financial Local Management Information System (LMIS), Local Financial Management.
\end{abstract}

\section{PENDAHULUAN}

Undang-Undang (UU) No. 23 Tahun 2014 memberikan kewenangan kepada Pemerintah Daerah (Pemda) untuk mengurus dan mengatur pemerintahannya sendiri, termasuk pengelolaan keuangan daerah yang pada akhirnya harus dipertanggungjawabkan kepada publik melalui penyajian laporan keuangan. Selanjutnya, Peraturan Pemerintah (PP) No. 65 Tahun 2010 tentang Sistem Informasi Keuangan Daerah (SIKD) mewajibkan Pemda untuk mengembangkan dan memanfaatkan kemajuan teknologi informasi.

Badan Pengawasan Keuangan dan Pembangunan (BPKP) selaku internal auditor dan pembina Sistem Pengendalian Intern Pemerintah (SPIP) menjawab tuntutan tersebut di atas sekaligus memfasilitasi Pemda dengan merancang suatu sistem informasi terintegrasi yang disebut Sistem Informasi Manajemen Daerah (SIMDA) Keuangan. Peran dan fungsi SIMDA Keuangan telah membantu pengelolaan keuangan daerah, sehingga wajib diawasi dan ditingkatkan penerapannya.

Pemerintah Kota (Pemkot) Manado telah menerapkan SIMDA Keuangan secara utuh sejak tahun 2012. Berdasarkan gambaran secara umum, masih terdapat beberapa kendala dan hambatan yang perlu dibenahi untuk dapat menerapkan SIMDA Keuangan secara optimal, 
antara lain; SIMDA Keuangan tidak terintegrasi dengan aplikasi sistem informasi dan komunikasi lainnya di Pemkot Manado, database yang tidak lengkap dan terpadu, tidak berbasis website secara online serta administrator database yang bukan PNS tetapi seorang tenaga kontrak/honorer. Berdasarkan latar belakang di atas, masalah dalam penelitian ini dirumuskan sebagai berikut.

1. Apa saja faktor-faktor pendukung yang dimiliki Pemerintah Kota Manado sehingga mampu menerapkan SIMDA Keuangan?

2. Bagaimana SIMDA Keuangan sebagai sistem informasi keuangan daerah dapat membantu tugas Pengelolaan Keuangan Daerah pada Pemerintah Kota Manado?

3. Bagaimana pengendalian internal SIMDA Keuangan dalam pengolahan data keuangan pada Pemerintah Kota Manado?

\section{TINJAUAN PUSTAKA}

\section{Teori Keagenan (Agency Theory)}

Agency Theory mendasarkan hubungan kontrak agar anggota-anggota dalam perusahaan, dimana prinsipal dan agen sebagai pelaku utama. Prinsipal merupakan pihak yang memberikan mandat kepada agen untuk bertindak atas nama prinsipal, sedangkan agen merupakan pihak yang diberi amanat oleh prinsipal untuk menjalankan perusahaan. Agen berkewajiban untuk mempertanggungjawabkan apa yang telah diamanahkan oleh prinsipal kepadanya. Inti dari Agency Theory atau teori keagenan adalah pendesainan kontrak yang tepat untuk menyelaraskan kepentingan prinsipal dan agen dalam hal terjadi konflik kepentingan (Scott, 1997).

\section{Implementasi Kebijakan}

Menurut Edward III (1980), implementasi kebijakan dipengaruhi oleh empat variabel, yaitu komunikasi (Communications), Sumber daya (resources), Sikap (disposition) dan struktur birokrasi (bureucratic structure). Keempat variabel tersebut dilaksanakan secara simultan karena antara satu dengan yang lainnya memiliki hubungan yang erat.

Menurut Donald S. Van Meter dan Carl E. Van Horn (dalam Subarsono, 2005), terdapat enam variabel yang memberikan pengaruh terhadap implementasi kebijakan, yakni: Pertama, standar dan sasaran kebijakan. Kedua, Sumber daya. Ketiga, hubungan antar organisasi. Keempat, karakteristik agen pelaksana yang mencakup struktur birokrasi, norma-norma dan pola-pola hubungan yang terjadi dalam birokrasi. Kelima, kondisi sosial politik dan ekonomi yang mencakup sumberdaya ekonomi lingkungan implementasi kebijakan. Keenam, Disposisi implementor.

\section{Konsep Sistem Informasi}

Sistem informasi menurut Leitch dan Davis (1983) adalah suatu sistem di dalam suatu organisasi yang mempertemukan kebutuhan pengolahan transaksi harian, mendukung operasi, bersifat manajerial dan kegiatan strategi dari suatu organisasi dan menyediakan bagi pihak luar tertentu berupa laporan-laporan yang diperlukan.

Menurut O’Brien dan Marakas (2011), Sistem informasi dapat merupakan kombinasi teratur dari orang-orang, hardware, software, jaringan komunikasi dan sumber daya data yang mengumpulkan, mengubah dan menyebarkan informasi dalam sebuah organisasi. Tiga peran utama sistem informasi dalam bisnis adalah (1). Mendukung proses bisnis dan operasional, (2). Mendukung pengambilan keputusan dan (3). Mendukung strategi untuk keunggulan kompetitif.

PP No. 65 Tahun 2010 tentang Sistem Informasi Keuangan Daerah menyebutkan bahwa Sistem Informasi Keuangan Daerah selanjutnya disebut SIKD adalah suatu sistem yang mendokumentasikan, mengadministrasikan serta mengolah data pengelolaan keuangan daerah dan data terkait lainnya menjadi informasi yang disajikan kepada masyarakat dan 
sebagai bahan pengambilan keputusan dalam rangka perencanaan, pelaksanaan dan pelaporan pertanggungjawaban pemerintah daerah.

\section{Teori Jaringan Aktor/Actor Network Theory (ANT)}

Pada dasarnya teori ANT (Latour, 2005), mengembangkan konsep tentang jaringan, aktor, translasi dan intermediari. Yang dapat dipahami bahwa konsep jaringan tidak hanya berfokus pada hubungan sosial aktor manusia, tetapi mencakup aktor-aktor non manusia-yaitu sebuah jaringan heterogen (beragam). ANT menggambarkan di antara manusia dan objek teknologi didalamnya berlangsung dua proses. Di satu pandangan adalah proses translasi dalam bentuk desain dan konstruksi. Namun di sisi lain adalah pembelajaran yang melewati pembuatan dan penggunaan.

\section{Sistem Informasi Manajemen Daerah (SIMDA) Keuangan}

Program aplikasi komputer SIMDA keuangan adalah suatu program aplikasi yang ditujukan untuk membantu pemerintah daerah dalam pengelolaan keuangan daerahnya. Dengan aplikasi ini, pemda dapat melaksanakan pengelolaan keuangan daerah secara terintegrasi, dimulai dari penganggaran, penatausahaan hingga akuntansi dan pelaporannya (BPKP, 2008). Fungsi utama pengimplementasian SIMDA Keuangan adalah sebagai berikut.

1. Membantu pemerintah daerah dalam melaksanakan pengelolaan keuangan daerah (penganggaran, pelaksanaan, pertanggungjawaban);

2. Menyusun laporan keuangan lebih efisien dan akurat;

3. Menyimpan data keuangan untuk keperluan manajemen lainnya;

4. Menyajikan informasi yang akurat secara efektif dan efisien yang akan digunakan oleh pengguna laporan; dan

5. Mempermudah proses audit bagi Auditor dengan merubah tata cara audit manual menjadi Electronic Data Processing (EDP) audit.

\section{Pengelolaan Keuangan Daerah}

Menurut PP Nomor 58 Tahun 2005, Pengelolaan Keuangan Daerah adalah keseluruhan kegiatan yang meliputi perencanaan, pelaksanaan, penatausahaan, pelaporan, pertanggungjawaban dan pengawasan keuangan daerah. Asas umum pengelolaan keuangan daerah adalah sebagai berikut.

1. Keuangan daerah dikelola secara tertib, taat pada peraturan perundang-undangan, efisien, ekonomis, efektif, transparan dan bertanggung jawab dengan memperhatikan asas keadilan, kepatutan dan manfaat untuk masyarakat; dan

2. Pengelolaan keuangan daerah dilaksanakan dalam suatu sistem yang terintegrasi yang diwujudkan dalam APBD yang setiap tahun ditetapkan dengan peraturan daerah.

\section{Pengendalian Internal dalam Sistem Informasi Akuntansi Terkomputerisasi}

Pengendalian khusus atau pengendalian aplikasi (application controls) ialah kontrol internal komputer yang berlaku khusus untuk aplikasi komputerisasi tertentu pada suatu organisasi (Gundodinyoto, 2007:371). Kategori pengendalian aplikasi dapat dilihat pada Tabel 2.1. 
Tabel 2.1 Kategori Pengendalian Aplikasi

\begin{tabular}{|l|l|}
\hline \multicolumn{1}{|c|}{ Kategori Pengendalian } & \multicolumn{1}{c|}{ Jenis-Jenis Pengendalian } \\
\hline 1. Boundary Control & $\begin{array}{l}\text { - Otoritas akses ke sistem aplikasi } \\
\text { - Identitas dan otentisitas pengguna }\end{array}$ \\
\hline 2. Input Control & $\begin{array}{l}\text { - Otoritas dan validasi masukan } \\
\text { - Transmisi dan konversi data } \\
\text { - Penanganan kesalahan }\end{array}$ \\
\hline 3. Process Control & $\begin{array}{l}\text { - Pemeliharaan ketepatan data } \\
\text { - Pengujian terprogram atas batasan dan memadainya } \\
\text { pengolahan }\end{array}$ \\
\hline 4. Output Control & $\begin{array}{l}\text { - Rekonsiliasi keluaran } \\
\text { - Penelaahan dan pengujian hasil pengolahan } \\
\text { - Distribusi keluaran } \\
\text { - Record retention }\end{array}$ \\
\hline 5. Database Control & $\begin{array}{l}\text { - Akses } \\
\text { - Integritas data }\end{array}$ \\
\hline 6. Communication Control & $\begin{array}{l}\text { - Pengendalian kegagalan unjuk kerja } \\
\text { - Gangguan komunikasi }\end{array}$ \\
\hline
\end{tabular}

Sumber: Diolah dari Weber, Vasarhelyi dan Lin (1988).

\section{Penelitian Terdahulu}

Penelitian Mitami (2013), dengan judul analisis penerapan sistem informasi manajemen daerah (SIMDA) Keuangan pada pemerintah daerah kabupaten pangkep, menggunakan metode deskriptif fenomenologi. Hasil dari penelitian menunjukkan bahwa secara umum pegawai DPKAD Pangkep sudah memahami makna SIMDA keuangan serta gambaran pelaksanaannya yang berkaitan dengan input dan output datanya. Faktor-faktor yang dimiliki untuk mendukung pelaksanaan penerapan SIMDA Keuangan yaitu komunikasi, sumber daya manusia, sikap/disposisi dan struktur birokrasi, adapun nilai-nilai yang dimiliki untuk menunjang penerapan SIMDA keuangan yaitu integritas, profesionalisme, komitmen, sinergi serta kesempurnaan.

Penelitian Nugraha (2013), dengan judul analisis implementasi sistem informasi manajemen daerah (SIMDA) terhadap kualitas laporan keuangan SKPD (studi kasus pada Dinas PPKAD Kabupaten Minahasa Tenggara), menggunakan metode kualitatif deskriptif. Hasil yang diperoleh dari penelitian ini bahwa: aplikasi SIMDA Keuangan sebagai sistem informasi akuntansi daerah telah mempermudah tugas pelaporan dan pengelolaan keuangan daerah, pengendalian intern sistem yang diterapkan guna mencapai tujuan pelaporan berjalan dengan baik dan aplikasi SIMDA Keuangan telah menghasilkan informasi laporan keuangan dan informasi keuangan lainnya dengan kualitas relevansi, akurasi dan ketepatan waktu yang lebih baik dari sebelumnya.

Penelitian Kahari, Kathogo dan Wanyoike (2015), dengan judul assessment of factors affecting the implementation of integrated financial management information system in the county governments: a case of Nyandarua County, Kenya. Penelitian ini menggunakan desain penelitian survei deskriptif terhadap sampel 70 karyawan. Analisis data menggunakan statistik deskriptif dan inferensial. Hasil penelitian menunjukkan bahwa terdapat hubungan yang kuat, negatif dan signifikan secara statistik antara resistensi staf dan implementasi IFMIS; dan bahwa ada hubungan yang kuat, positif dan signifikan secara statistik antara kapasitas dan keterampilan pengguna IFMIS dan pelaksanaannya.

Proposisi yang dapat ditetapkan sebagai pernyataan awal untuk menjawab pertanyaan riset dan memberikan solusi terhadap permasalahan dalam penelitian ini adalah sebagai berikut. 
1. Penerapan SIMDA Keuangan secara optimal harus didukung oleh faktor-faktor seperti: komunikasi, sumber daya, disposisi/sikap dan struktur birokrasi yang memadai;

2. Sebagai sistem informasi keuangan daerah, SIMDA Keuangan sangat penting dan sangat bermanfaat dalam membantu pengelolaan keuangan daerah secara terintegrasi; dan

3. SIMDA Keuangan telah didukung dengan pengendalian internal yang memadai untuk memastikan efektivitas dan efisiensi penerapan sistem yang dirancang.

\section{METODE PENELITIAN}

\section{Jenis Penelitian}

Metode yang digunakan dalam penelitian ini adalah metode kualitatif deskriptif. Penelitian dengan menggunakan metode ini bertujuan untuk menggambarkan, meringkaskan berbagai kondisi, berbagai situasi atau berbagai fenomena realitas sosial yang ada di masyarakat yang menjadi objek penelitian dan berupaya menarik realitas itu ke permukaan sebagai suatu ciri, karakter, sifat, model, tanda atau gambaran tentang kondisi, situasi ataupun fenomena tertentu (Bungin, 2007:68). Pendekatan yang digunakan adalah fenomenologi, dimana penelitian ini dilakukan dengan situasi yang alami, sehingga tidak ada batasan dalam memaknai atau memahami fenomena yang dikaji. Creswell (2003:15) menyebutkan bahwa "dalam studi fenomenologi yang diteliti adalah pengalaman manusia melalui deskripsi dari orang yang menjadi partisipan penelitian, sehingga peneliti dapat memahami pengalaman hidup partisipan".

\section{Jenis dan Sumber Data}

Penelitian ini menggunakan data kualitatif berupa hasil wawancara mendalam kepada beberapa informan kunci pada Badan Pengelola Keuangan dan Barang Milik Daerah (BPKBMD) Pemerintah Kota Manado serta dokumen/arsip SKPD berupa gambaran umum, struktur organisasi dan job description. Sumber data yang digunakan pada penelitian ini adalah sebagai berikut.

1. Data primer, yaitu data yang diperoleh dengan melakukan wawancara langsung kepada informan kunci yaitu Kepala BPK-BMD, Kepala Bidang Anggaran, Kepala Bidang Akuntansi, Kepala Bidang Perbendaharaan dan Database Administrator SIMDA Keuangan.

2. Data Sekunder, yaitu data yang diperoleh dari dokumen-dokumen yang berkaitan dengan pembahasan, literatur, serta sumber lainnya yang berkaitan dengan objek penelitian.

\section{Teknik Pengumpulan Data}

Menurut Sugiyono (2014:62), teknik pengumpulan data merupakan langkah yang paling strategis dalam penelitian, karena tujuan utama dalam penelitian adalah mendapatkan data. Tanpa mengetahui teknik pengumpulan data, maka tidak mungkin akan mendapatkan data yang memenuhi standar data yang ditetapkan. Teknik pengumpulan data yang ditempuh dalam penelitian ini adalah melalui wawancara mendalam (indepth interview), pengamatan/observasi (observation) dan dokumentasi (documentation).

\section{Teknik Pengujian Keabsahan Data}

Menurut Sugiyono (2014:120) uji keabsahan data dalam penelitian kualitatif meliputi uji credibility (validitas internal), transferability (validitas eksternal), dependability (reliabilitas) dan confirmability (objektivitas). Penelitian ini menggunakan metode triangulasi dalam pengujian kredibilitas, yaitu dengan cara pengecekan data dari berbagai sumber dengan berbagai cara dan berbagai waktu. 


\section{Instrumen Penelitian}

Dalam penelitian kualitatif, yang menjadi instrumen atau alat penelitian adalah peneliti itu sendiri. Oleh karena itu, peneliti sebagai instrumen juga harus "divalidasi" seberapa jauh peneliti kualitatif siap melakukan penelitian yang selanjutnya turun ke lapangan (Sugiyono, 2014).

\section{Lokasi dan Waktu Penelitian}

Penelitian dilakukan di Badan Pengelola Keuangan dan Barang Milik Daerah (BPK-BMD) Kota Manado yang merupakan pusat access point dan server aplikasi SIMDA Keuangan Pemerintah Kota Manado. Waktu Penelitian selama kurang lebih 4 (empat) bulan, sejak Mei sampai dengan Agustus 2016, yang dimulai dari tahap penyusunan usulan penelitian (proposal) sampai tesis selesai dirampungkan.

\section{Informan Penelitian}

Informan yang terpilih dalam penelitian ini dapat dilihat pada Tabel 4.1.

Tabel 4.1 Data Informan

\begin{tabular}{|l|l|l|l|}
\hline NO. & \multicolumn{1}{|c|}{ NAMA dan NIP } & \multicolumn{1}{|c|}{$\begin{array}{c}\text { Pangkat, } \\
\text { Golongan/Ruang }\end{array}$} & \multicolumn{1}{|c|}{ Jabatan } \\
\hline 1. & $\begin{array}{l}\text { Drs. Manarsar Pandjaitan, M.Si } \\
\text { NIP. 19631128 198503 1 001 }\end{array}$ & $\begin{array}{l}\text { Pembina Utama Muda, } \\
\text { IV/c }\end{array}$ & $\begin{array}{l}\text { Kepala BPK-BMD } \\
\text { (PPKD/BUD) }\end{array}$ \\
\hline 2. & $\begin{array}{l}\text { Ir. M. V. S. Tulenan, M.Si } \\
\text { NIP. 19660528 199803 2 004 }\end{array}$ & $\begin{array}{l}\text { Pembina, } \\
\text { IV/a }\end{array}$ & Kepala Bidang Anggaran \\
\hline 3. & $\begin{array}{l}\text { Florensia S. Pedah, SE, M.Si, Ak, } \\
\text { CA } \\
\text { NIP. 19761022 200212 2 002 }\end{array}$ & $\begin{array}{l}\text { Penata Tingkat I, } \\
\text { III/d }\end{array}$ & Kepala Bidang Akuntansi \\
\hline 4. & $\begin{array}{l}\text { J. J. Mangindaan, SE, S.ST, MM, } \\
\text { Ak } \\
\text { NIP. 19700705 199703 2 005 }\end{array}$ & $\begin{array}{l}\text { Pembina, } \\
\text { IV/a }\end{array}$ & $\begin{array}{l}\text { Kepala Bidang } \\
\text { Perbendaharaan (Kuasa } \\
\text { BUD) }\end{array}$ \\
\hline 5. & Raphi Mardiyono, A.Md & Tenaga Kontrak & $\begin{array}{l}\text { Administrator Database } \\
\text { SIMDA Keuangan }\end{array}$ \\
\hline
\end{tabular}

Sumber: BPK-BMD Kota Manado (data diolah).

\section{Teknik Analisis Data}

Langkah-langkah analisis data yang dikembangkan pada penelitian ini adalah sebagai berikut.

1. Data dari wawancara, observasi dan dokumentasi diorganisir kesamaan dan perbedaannya sesuai dengan rumusan masalah dan pertanyaan penelitian;

2. Data yang sudah diorganisir ditentukan temanya;

3. Mencari keterkaitan antara tema;

4. Interpretasi atas semua temuan sesuai dengan keterkaitan antar tema dengan menggunakan teori/konsep yang relevan; dan

5. Hasil interpretasi dituangkan secara deskriptif analisis kontekstual.

\section{HASIL ANALISIS DAN PEMBAHASAN}

Data wawancara, data dokumentasi dan data observasi langsung yang diperoleh, kemudian dilakukan organisasi data yaitu kategorisasi dan coding berdasarkan rumusan masalah dan pertanyaan penelitian. Selanjutnya dilakukan pemahaman untuk menemukan tema yang ada. Untuk menjawab masalah pertama yaitu "apa saja faktor-faktor pendukung yang dimiliki Pemerintah Kota Manado sehingga mampu menerapkan SIMDA Keuangan" ditemukan empat tema yaitu komunikasi, sumber daya, disposisi/sikap dan struktur birokrasi.

Untuk menjawab masalah kedua yaitu "bagaimana SIMDA Keuangan sebagai sistem informasi keuangan daerah dapat membantu tugas Pengelolaan Keuangan Daerah pada Pemerintah Kota Manado" ditemukan tiga tema yaitu operasional organisasi, pengambilan 
keputusan dan sasaran strategis. Untuk menjawab masalah ketiga yaitu "bagaimana pengendalian internal SIMDA Keuangan dalam pengolahan data keuangan pada Pemerintah Kota Manado" ditemukan empat tema yaitu pengendalian akses dan wewenang user, pengendalian keamanan umum, pengendalian menu berdasarkan fungsi dan pengendalian aplikasi.

Berdasarkan hasil penelitian yang diperoleh dari wawancara, observasi dan dokumentasi, selanjutnya dilakukan interpretasi atas temuan yang ada sesuai dengan dengan teori/konsep yang mendukung hasil penelitian. Adapun analisis terhadap hasil penelitian dan pembahasan dapat diuraikan sebagai berikut.

\section{Faktor-Faktor Pendukung yang Dimiliki oleh Pemerintah Kota Manado dalam Penerapan SIMDA Keuangan}

Penerapan SIMDA Keuangan yang dilakukan oleh Pemerintah Kota Manado tentunya tidak lepas dari prakondisi yang menjadi faktor pendukungnya. Dari hasil penelitian, berbagai faktor pendukung yang dimiliki untuk menerapkan SIMDA Keuangan adalah sebagai berikut.

1. Komunikasi

Untuk penerapan SIMDA Keuangan yang optimal pada Pemerintah Kota Manado telah didukung oleh adanya komunikasi yang aktif dari semua pihak yang terkait. Hal ini sesuai dengan teori implementasi kebijakan menurut Edward III (1980) dimana komunikasi merupakan faktor penentu keberhasilan penerapan. Menurut Donald S. Van Meter dan Carl E. Van Horn (dalam Subarsono, 2005), dalam banyak program, implementasi sebuah program perlu dukungan dan koordinasi dengan instansi lain. untuk itu, diperlukan koordinasi dan kerjasama dengan instansi lain agar sasaran kebijakan/program tercapai.

2. Sumber Daya

Penerapan SIMDA Keuangan pada Pemerintah Kota Manado didukung oleh beberapa komponen, yaitu: sumber daya manusia yang memang handal/memenuhi baik dalam jumlah maupun kapasitasnya, peningkatan kemampuan/keterampilan SDM melalui kegiatan bimbingan teknis (BimTek) yang teratur dan rutin dilaksanakan dan sumber daya hardware dan software yang memadai dan saling mendukung. Menurut Edward III (1980), komponen sumber daya meliputi jumlah staf, keahlian dari para pelaksana, informasi yang relevan serta cukup untuk menerapkan kebijakan dan pemenuhan sumber-sumber terkait dalam pelaksanaan kebijakan, adanya wewenang yang menjamin bahwa kebijakan dapat diarahkan sebagaimana yang diharapkan serta adanya fasilitas-fasilitas pendukung yang dapat dipakai untuk melakukan kegiatan seperti dana dan sarana prasarana.

Walaupun semua sumber daya yang dibutuhkan untuk penerapan SIMDA Keuangan pada Pemerintah Kota Manado sudah tersedia, tetapi masih ada hal yang perlu dibenahi dan ditingkatkan yaitu mengenai ruang entry data. Ruangan yang ada saat ini sangat kecil dan sempit, tidak memadai untuk aktivitas operasional SIMDA Keuangan bagi operator SKPD. Selain itu juga, perlu diperhatikan dan ditingkatan untuk ketersediaan sumber daya data dan jaringan untuk optimalisasi penerapan SIMDA Keuangan sehingga dapat mendukung pelaksanaan setiap tugas dan fungsi Pemerintah Daerah.

3. Disposisi/Sikap

Respon terhadap penerapan SIMDA Keuangan di Pemerintah Kota Manado sudah baik sehingga penerapannya dapat terlaksana dengan baik dan dilaksanakan dengan senang hati oleh setiap implementor. Dalam penerapan SIMDA Keuangan pada Pemerintah Kota Manado telah didukung sepenuhnya oleh Kepala BPK-BMD selaku PPKD, sehingga tidak heran jika para pegawai dapat menjalankannya secara optimal. Menurut Donald S. Van Meter dan Carl E. Van Horn (dalam Subarsono, 2005), 
disposisi implementor yang mencakup tiga hal yang penting yaitu: 1).Respon implementor terhadap kebijakan yang akan mempengaruhi kemauan untuk melaksanakan kebijakan; 2).Kognisi, yaitu pemahamannya terhadap kebijakan; dan

3).Intensitas disposisi implementor.

4. Struktur Birokrasi

Pemerintah Kota Manado belum tertib dalam hal struktur birokrasi dan organisasi pengelolaan SIMDA Keuangan. Tidak ada Tim Pengelola SIMDA yang ditetapkan melalui SK, sehingga berbagai fungsi dijalankan dengan sangat fleksibel. Pemisahan tugas dan fungsi pengelola serta pendelegasian wewenang dan tanggung jawab dalam penerapan SIMDA Keuangan tidak berjalan sebagaimana mestinya suatu organisasi atau pun sub-unit yang ada didalamnya. Hal ini tidak sejalan dengan apa yang dikehendaki oleh Satgas Pengembangan SIMDA Keuangan(BPKP, 2008), dalam hal sumber daya manusia untuk penerapan SIMDA Keuangan.

SIMDA Keuangan Sebagai Sistem Informasi Keuangan Daerah Dapat Membantu Tugas Pengelolaan Keuangan Daerah pada Pemerintah Kota Manado

SIMDA Keuangan berperan penting bagi Pemerintah Kota Manado, dalam hal sebagai berikut:

\section{Operasional Organisasi}

Penerapan SIMDA Keuangan pada Pemerintah Kota Manado berperan penting dalam mendukung operasional SKPKD, mulai dari bidang penganggaran, akuntansi sampai pada perbendaharaan. Kecuali untuk efektifitas dan efisiensi tugas pemerintahan dalam hal konektivitas dan integrasi aplikasi sistem informasi dan komunikasi masih perlu dibenahi dan ditingkatkan. Hal ini sejalan dengan konsep sistem informasi yang menyatakan bahwa kemampuan sistem informasi untuk dapat mengumpulkan dan mengintegrasikan informasi ke berbagai fungsi bisnis menjadi kritis/penting sehingga mendukung proses bisnis dan operasional organisasi (O’Brien dan Marakas, 2001).

\section{Pengambilan Keputusan}

Penerapan SIMDA Keuangan pada Pemerintah Kota Manado dapat menghasilkan informasi secara cepat, tepat dan akurat sehingga mendukung pengambilan keputusan yang lebih cepat dan bermakna oleh pihak yang berwenang. Hal ini sejalan dengan konsep sistem informasi yang mengemukakan bahwa Sistem informasi dapat mengkombinasikan informasi untuk membantu manajer menjalankan bisnis dengan lebih baik, informasi yang sama dapat membantu para manajer mengidentifikasikan kecenderungan dan untuk mengevaluasi hasil dari keputusan sebelumnya. Sistem Informasi akan membantu para manajer membuat keputusan yang lebih baik, lebih cepat dan lebih bermakna (O'Brien dan Marakas, 2001). Tujuan pengembangan aplikasi SIMDA Keuangan (BPKP, 2008), salah satunya adalah menghasilkan informasi yang komprehensif, tepat dan akurat kepada manajemen pemerintah daerah. Informasi ini dapat digunakan sebagai bahan untuk mengambil keputusan.

\section{Sasaran Strategis}

penerapan SIMDA Keuangan pada Pemerintah Kota Manado dapat mendukung pencapaian tujuan dan sasaran strategis organisasi BPK-BMD selaku SKPKD. Hal ini sesuai dengan konsep sistem informasi yang menyatakan bahwa sistem informasi yang dirancang untuk membantu pencapaian sasaran strategis organisasi dapat menciptakan keunggulan bersaing (O’Brien dan Marakas, 2011).

\section{Pengendalian Internal SIMDA Keuangan Dalam Pengolahan Data Keuangan pada}

\section{Pemerintah Kota Manado}

Terdapat beberapa jenis pengendalian internal yang diterapkan dalam pengolahan data keuangan melalui aplikasi SIMDA Keuangan, yaitu pengendalian akses dan wewenang user, pengendalian keamanan umum, pengendalian menu berdasarkan fungsi dan pengendalian aplikasi. 


\section{Pengendalian Akses dan Wewenang User}

Penerapan SIMDA Keuangan pada Pemerintah Kota Manado telah dilengkapi dengan pengendalian akses dan wewenang user yang menjamin keamanan data yang diolah SIMDA Keuangan. Hal ini sesuai dengan manfaat penerapan SIMDA Keuangan yang terintegrasi (BPKP, 2008). Aplikasi SIMDA dapat diimplemetasikan untuk pengelolaan keuangan daerah secara terintegrasi, menggunakan teknologi multi user dan teknologi client/server, dari penyusunan anggaran, pelaksanaan anggaran dan pertanggungjawaban keuangan baik dilaksanakan di SKPKD maupun di SKPD. Weber (1988) juga menyebutkan tentang pengendalian batas (boundary control) yang meliputi adanya otoritas akses ke sistem aplikasi dan mengatur identitas serta otentisitas pengguna.

\section{Pengendalian Keamanan Umum}

Penerapan SIMDA Keuangan pada Pemerintah Kota Manado dapat menjamin keamanan data yang diolah melalui pengendalian keamanan secara fisik. Hal ini sejalan dengan manfaat penerapan SIMDA Keuangan yang terintegrasi (BPKP, 2008), dimana salah satunya menyebutkan adanya kesinambungan pemeliharaan hardware dan software dengan mendapat dukungan penuh dari pimpinan serta dibantu oleh eksistensi BPKP Perwakilan. Walaupun pengendalian keamanan umum dalam penerapan SIMDA Keuangan pada Pemerintah Kota Manado telah mampu dilaksanakan melalui pemeliharaan dan pengamanan semua sarana pendukung secara fisik, tetapi masih terdapat kekurangan, antara lain: ruang server masih kurang aman karena dinding tidak terbuat dari beton tetapi hanya papan dan sekat kaca sehingga pendingin ruangan (AC) pun tidak bisa berfungsi secara maksimal dan air AC dapat merusak dinding kayu. Selain itu instalasi kabel listrik tidak aman karena hanya menempel di dinding kayu dan sekat kaca tidak masuk ke dalam beton seperti yang seharusnya.

\section{Pengendalian Menu Berdasarkan Fungsi}

penerapan SIMDA Keuangan pada Pemerintah Kota Manado telah menjalankan pengendalian menu berdasarkan fungsi untuk menjamin keamanan data per bidang di SKPKD dan untuk validitas input data. Hal ini sesuai dengan pendapat Weber (1988) yang mengemukakan pengendalian jenis ini dalam bentuk pengendalian basis data (database control) melalui pengendalian validitas dan integritas data. BPKP (2008) juga menyatakan bahwa salah satu manfaat penerapan aplikasi SIMDA Keuangan yang terintegrasi adalah menjamin pengendalian transaksi dari setiap fungsi/bidang yang ada yaitu; penganggaran, penatausahaan, akuntansi dan pelaporan.

\section{Pengendalian Aplikasi}

Penerapan SIMDA Keuangan pada Pemerintah Kota Manado telah menjalankan pengendalian aplikasi dengan baik melalui pengendalian masukan, pengendalian proses dan pengendalian keluaran untuk memastikan aplikasi SIMDA Keuangan telah berjalan dengan baik dan memenuhi harapan. Hal ini sesuai dengan Keunggulan atau nilai tambah yang ditawarkan oleh SIMDA Keuangan (BPKP, 2008), yaitu: output/laporan disesuaikan dengan peraturan yang berlaku dan fleksibel, dapat menghasilkan informasi sesuai dengan kebutuhan; berbasis windows; validasi Inputan data lebih terjamin dan terdapat menu otoritas dan unit otoritas.

\section{KESIMPULAN DAN SARAN Kesimpulan}

Berdasarkan hasil analisis terhadap kondisi yang dijumpai dalam penelitian, maka kesimpulan yang dapat ditarik dalam penelitian ini adalah sebagai berikut.

1. Pemerintah Kota Manado telah memiliki beberapa faktor pendukung dalam penerapan SIMDA Keuangan, tetapi ada juga beberapa faktor pendukung yang belum terpenuhi, antara lain sebagai berikut. 
a. Komunikasi aktif telah dilakukan oleh semua pihak yang terkait dengan penerapan SIMDA Keuangan. Adanya komitmen pimpinan selaku pembuat kebijakan untuk memahami maksud dan tujuan penerapan kebijakan serta didukung dengan pemahaman bersama dari semua implementor tentang SIMDA Keuangan. Sosialisasi sebelum penerapan dan komunikasi selama penerapan dengan semua implementor pada Pemerintah Kota Manado dan juga pendampingan dari Tim Pengawasan BPKP Perwakilan Propinsi SULUT menjadikan aplikasi SIMDA Keuangan mampu dijalankan secara optimal.

b. Sumber Daya yang saling mendukung satu dengan yang lainnya. Sumber daya manusia yang ada dan dipersiapkan untuk penerapan SIMDA Keuangan memang handal/memenuhi baik dalam jumlah maupun kapasitasnya, peningkatan kemampuan/keterampilan SDM melalui kegiatan bimbingan teknis (BimTek) yang teratur dan rutin dilaksanakan serta didukung oleh ketersediaan sumber daya hardware dan sumber daya software yang memadai.

Sumber daya manusia dalam hal ketersediaan administrator database belum terpenuhi karena SDM yang ada saat ini hanya seorang tenaga kontrak.

Sumber daya data belum lengkap, terpadu dan komprehensif, sehingga tidak efisien dalam penerapan SIMDA Keuangan, karena setiap penyusunan anggaran tahun berikutnya harus dilakukan entry data secara berulang-ulang.

Sumber daya jaringan tidak mendukung fungsi pengambilan keputusan oleh eksekutif (Walikota) dan fungsi monitoring oleh legislatif (DPRD).

c. Disposisi/Sikap yang baik untuk menerima/setuju dengan penerapan SIMDA Keuangan dan melaksanakannya dengan senang hati serta didukung oleh komitmen dan sikap demokrasi dari pimpinan.

d. Struktur Birokrasi/Organisasi pengelolaan SIMDA Keuangan belum tertib dilakukan oleh Pemerintah Kota Manado karena tidak ada SK Tim Pengelola SIMDA Keuangan di Pemerintah Kota Manado sesuai yang disyaratkan oleh Satgas Pengembangan SIMDA Keuangan-BPKP.

2. Sebagai sistem informasi keuangan daerah, SIMDA Keuangan sangat penting dan sangat bermanfaat dalam membantu pengelolaan keuangan daerah secara terintegrasi pada Pemerintah Kota Manado serta berperan dalam rangka:

a. mendukung operasional organisasi pada setiap bidang; penganggaran, akuntansi dan perbendaharaan;

b. mendukung pengambilan keputusan oleh pihak yang berwenang melalui penyajian informasi secara cepat, tepat dan akurat; dan

c. mendukung pencapaian tujuan dan sasaran strategis organisasi.

Namun, SIMDA Keuangan tidak terintegrasi dengan aplikasi sistem informasi dan komunikasi lainnya di Pemerintah Kota Manado sehingga tugas pemerintahan menjadi tidak efektif dan efisien dalam mewujudkan good governance.

3. Dalam pengolahan data keuangan pada Pemerintah Kota Manado, SIMDA Keuangan telah didukung dengan pengendalian internal yang cukup memadai untuk memastikan efektivitas dan efisiensi penerapan sistem yang telah dirancang melalui beberapa jenis pengendalian, antara lain sebagai berikut.

a. pengendalian akses dan wewenang user yang memungkinkan pembatasan akses aplikasi SIMDA Keuangan yang ditujukan hanya kepada pihak tertentu seperti operator SIMDA Keuangan;

b. pengendalian keamanan umum yang dilakukan secara fisik;

c. pengendalian menu berdasarkan fungsi untuk menjamin validitas input data aplikasi SIMDA Keuangan secara terintegrasi; dan 
d. pengendalian aplikasi untuk memastikan bahwa sistem yang diaplikasikan telah berjalan sesuai yang diharapkan dan menjamin bahwa seluruh transaksi yang diproses dalam aplikasi SIMDA Keuangan merupakan transaksi yang valid, terotorisasi dan dicatat secara lengkap, akurat dan benar melalui pengendalian masukan, pengendalian proses dan pengendalian keluaran.

\section{Saran}

Untuk dapat menerapkan SIMDA Keuangan secara maksimal pada Pemerintah Kota Manado, ada beberapa hal yang dapat disarankan untuk menjadi perhatian demi perbaikan ke depan antara lain sebagai berikut.

1. Untuk peningkatan SDM implementor SIMDA Keuangan, seharusnya diadakan atau diikutsertakan pelatihan khusus bagi administrator database dan operator SKPKD dalam rangka continuous improvement.

2. Sumber daya data harus dilengkapi dalam rangka efektivitas dan efisiensi pengelolaan keuangan daerah dan sumber daya jaringan perlu dibenahi dengan membuat koneksi secara online berbasis website untuk mendukung pelaksanaan tugas dan fungsi pengambilan keputusan eksekutif dan monitoring legislatif serta bisa menjadi media pertanggungjawaban publik.

3. Pemerintah Kota Manado harus mengatur dengan jelas dan menetapkan dengan Surat Keputusan (SK) Walikota untuk Tim Pengelola SIMDA dengan struktur dan komposisi personil seperti yang disyaratkan oleh Satgas Pengembangan SIMDA Keuangan BPKP yang terdiri dari: penanggung jawab, pembantu penanggung jawab, pengendali teknis, ketua tim dan beberapa anggota tim; administrator database, asisten administrator dan timnya, serta seluruh operator SKPD.

4. Pemerintah Kota Manado harus mempersiapkan administator database yang kompeten; mahir dalam menggunakan komputer, menguasai program database, memahami pentingnya pengamanan data dan antusiasme tinggi untuk mempelajari sistem informasi teknologi serta harus merupakan Aparatur Sipil Negara (ASN)/Pegawai pada BPK-BMD Kota Manado untuk tujuan jangka panjang, karena administrator database yang ada sekarang adalah seorang tenaga kontrak yang setiap saat bisa saja keluar dari Pemerintah Kota Manado.

5. Ruang entry data SIMDA Keuangan yang ada saat ini sangat kecil dan sempit sehingga perlu disediakan tempat yang lebih memadai dan bisa menampung semua operator SKPD dalam mengoperasikan SIMDA Keuangan dengan lebih baik dan nyaman.

6. Ruang server yang ada saat ini belum memadai sesuai standar keamanan karena hanya berdinding papan dan sekat kaca sehingga perlu diperbaiki dan harus dibuat dinding beton. Begitu pula dengan instalasi kabel listrik yang hanya menempel sepanjang dinding papan dan sekat kaca perlu diatur dan dibenahi supaya aman dan bisa bermanfaat untuk jangka panjang.

7. Untuk penelitian selanjutnya, supaya lebih menggali topik atau tema-tema yang lain sehubungan dengan penerapan SIMDA Keuangan selain faktor pendukung, mekanisme pengelolaan keuangan daerah atau pengendalian internal sistem/aplikasi.

\section{DAFTAR PUSTAKA}

Bungin, Burhan. 2007. Penelitian Kualitatif; Komunikasi, Ekonomi, Kebijakan Publik dan Ilmu Sosial Lainnya. Jakarta: KENCANA.

Creswell, John W. 2003. Research Design: Qualitative, Quantitative and Mixed Methods Approaches. California: Sage Publications, Inc. 
Edwards , George C. III. 1980. "Implementing Public Policy". Washington DC: Congresional, Quartely Press.

Grizzle, Gloria A. dan Carole D. Pettijohn, 2002, "Implementing Performance-Based Program Budgeting: A System-Dynamic Perspective", Public Administration Review, Jan/Feb 2002;62,1.

Gundodiyoto, Sanyoto. 2007. Audit Sistem Informasi + Pendekatan Cobit. Jakarta: Mitra Wacana Media.

Kahari, Gathogo dan Wanyoike. 2015. "Assessment Of Factors Affecting The Implementation Of Integrated Financial Management Information System In The County Governments: A Case Of Nyandarua County, Kenya", International Journal of Economics, Commerce and Management. Volume III. United Kingdom.

Leitch, Robert A. Dan Davis, K. Roscoe. 1983. Accounting Information Systems. New Jersey: Prentice Hall.

Latour, Bruno. 2005. Reassembling the Social. New York: Oxford University Press.

Mitami, Dian M. 2013. Analisis Penerapan Sistem Informasi Manajemen Daerah (SIMDA) Keuangan pada Pemerintah Daerah Kabupaten Pangkep. Skripsi tidak diterbitkan. Makassar: Fakultas Ekonomi dan Bisnis Universitas Hasanuddin.

O'Brien, James A. dan Marakas, George M. 2011. Management Information Systems-10 ${ }^{\text {th }}$ edition. New York: McGraw Hill/Irwin.

PP Nomor 58 Tahun 2005 tentang Pengelolaan Keuangan Daerah. 2005. Jakarta: Departemen Keuangan Republik Indonesia.

PP Nomor 65 Tahun 2010 tentang Sistem Informasi Keuangan Daerah. 2010. Jakarta: Departemen Keuangan Republik Indonesia.

Satgas Pengembangan SIMDA 2008. SIMDA dan Penerapannya. Jakarta: Badan Pemeriksa Keuangan dan Pembangunan.

Subarsono. 2005. Analisa Kebijakan Publik. Yogyakarta: Pustaka Pelajar.

Sugiyono. 2014. Memahami Penelitian Kualitatif. Bandung: Alfabeta.

Undang-Undang Nomor 23 Tahun 2014 Tentang Pemerintahan Daerah. 2014. Jakarta: Departemen Keuangan Republik Indonesia.

Vasarhelyi, Miklos dan Thomas, W. Lin. 1988. Advanced auditing: Fundamentals of EDP and Statistical Auditing Technology. Reading, Mass.: Addison-Wesley.

Weber, Ron. 1988. EDP auditing: Conceptual Foundations and Practice, 2nd edition. New York: McGraw-Hill. 